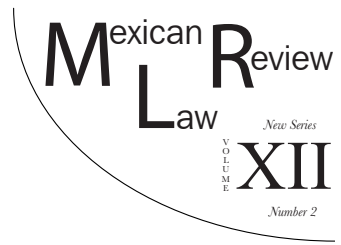

\title{
MEXICO 2018: AN OPPORTUNITY FOR POPULAR GONSTITUTIONALISM
}

\author{
Roberto Niembro O.*
}

\begin{abstract}
In 2018 Mexicans chose the most profound political change since the transition to democracy, leaving behind what in another work I have called authoritarian constitutionalism. The alternation has meant a change of regime in which a social transformation is announced. The transformation can take different paths and must be accompanied by ideas that inspire it. In this frame of mind, popular constitutionalism can be a useful theory in order for the transformation to take a democratic, participative and egalitarian direction, since it fosters political participation and democratic equality. It is time to forego the elitist theories of constitutional law and the minimalist understandings of democracy.
\end{abstract}

KEYwORDs: Participation, popular constitutionalism, transformative constitutionalism, Mexico.

RESUMEN: En 2018 los mexicanos y mexicanas elegimos el cambio político más profundo desde la transición a la democracia, dejando atrás lo que en otro trabajo he denominado constitucionalismo autoritario. La alternancia ha significado un cambio de régimen en el que se anuncia una transformación social. La transformación puede tomar distintos rumbos y debe ser acompañada por ideas que la inspiren. En esta tesitura, el constitucionalismo popular puede ser una teoría útil para que la transformación sea en una dirección democrática, participativa e igualitaria, pues incentiva la participación politica y la igualdad democrática. Es momento de dejar atrás las teorías elitistas del derecho constitucionaly las concepciones minimalistas de la democracia.

Palabras clave: Participación, constitucionalismo popular, constitucionalismo transformador, México.

* PhD in Law from the Universidad Complutense de Madrid. Master's in Legal Theory from New York University (Hauser Global Scholar). Law degree from the Escuela Libre de Derecho. Professor of Constitutional Law in the ITAM. Editor of the book Constitucionalismo popular en Latinoamérica (2013) along with Micaela Alterio, and of the book Constitucionalismo progresista: Retos y Perspectivas. Un homenaje a Mark Tushnet (2016) along with Roberto Gargarella. 
Esta revista forma parte del acervo de la Biblioteca Jurídica Virtual del Instituto de Investigaciones Jurídicas de la UNAM

\section{Table of Contents}

I. INTRODUCTION

1. Mexico Has Lived under Authoritarian

Constitutionalism

A. Creating Continuous Apirations through the Constitution and other Legal Instruments

B. Making Implausible any Real Change

C. Some Examples

II. Popular Gonstitutionalism as a Source of Inspiration for Constitutional Transformation

III. Popular Participation as an Indispensable Mechanism for Constitutional Transformation

IV. Gonclusions .

\section{INTRODUCTION}

We live in a moment of political alternation in which a national transformation is being announced. This alternation has meant a change of political elites and a different way of doing politics. There is no doubt that Mexico's transformation is urgent in different spheres, particularly in those in which structural inequalities exist. ${ }^{1}$ In constitutional matters, this transformation can take different paths, because the alternation alone does not ensure us that it will advance towards a regime of rights and freedoms or towards an authentically democratic system.

In his article about transformative constitutionalism, Klare defined this as:

A long-term Project of constitutional enactment, interpretation and enforcement committed (not in isolation, of course, but in historical context of conductive political developments) to transforming a country's political and social institutions and power relationships in a democratic, participatory, and egalitarian direction. Transformative constitutionalism connotes an enterprise of inducing large-scale social change through nonviolent political processes grounded in law. I have in mind a transformation vast enough to be inadequately captured by the phrase "reform", but something short of or different from "revolution" in any traditional sense of the word. ${ }^{2}$

1 See Pius Langa, Transformative Constitutionalism, StelL. LR 2006, 352.

2 Karl E. Klare, Legal Culture and Transformative Constitutionalism, SOUTH AFRICAN JOURNAL ON HUMAN RIGHTS 146 (1998). 
In order for Mexico's constitutional transformation to take a democratic, participatory and egalitarian direction as Klare proposed for South Africa, and which we yearn for also, popular constitutionalism can be a source of inspiration. In Mexico during the 20th century and the ongoing 21st century the institutional design and the prevailing democratic ideas were inspired by elitist understandings of constitutional law that sideline popular participation in the creation, interpretation and application of the constitution, in as much as these consider that citizens are not able to debate on constitutional topics. Also, these are based in a minimalist conception of democracy that is focused solely in elections and the electoral process, without taking into account the importance of the involvement of citizens and their active participation during the lapse from one election to another.

As I have argued elsewhere, the phase that recently ended in 2018 can be deemed as an authoritarian constitutionalism, in which the liberal democratic constitution in force had been used by political elites for authoritarian purposes. ${ }^{3}$ This phase started with what a few have called the "transition towards democracy". For some the transformation has already taken place and, therefore, it is unnecesary to think about it. I obviously do not share this outlook of the democratic transition, for as I have mentioned for several years, we have lived in a sort of authoritarian constitutionalism.

The starting point to outline a constitutional transformation is not a trivial matter, because the proposed change is made about the existing situation. That way, if our starting point is that the system currently in force is that of a more or less functional democracy, then there is no need for a transformation but for a reform instead. However, if the status quo is a sort of authoritarian constitutionalism, there is no other choice but to make a transformation. Even more, understanding authoritarian constitutionalism as a starting point can prevent us from erring upon the path, because it shows that a series of reforms is not enough to carry out the transformation. In fact, in this new phase it will be crucial not to make the same mistake as in the past, which is to consider that some liberal and democratic legal modifications are enough to eradicate our authoritarian culture and practices. ${ }^{4}$

In the achievement of this constitutional transformation, the academy has the responsibility to contribute intellectually to its accomplishment, because we cannot just notice the historic moment and wait to be part of it in our own benefit. Hence, for the announced transformation to be truly significant and to become a deep change it must be oriented towards a sort of popular constitutionalism. To understand how this change can be achieved, I will describe a few of the main characteristics of the authoritarian constitutionalism that we live in, I will take up the thesis that upholds popular constitutionalism as

3 Roberto Niembro Ortega, Conceptualizing authoritarian constitutionalism, 4 VRÜ, 2016, 339.

4 Jaime Cárdenas Gracia, Popular Constitutionalism and Forms of Democracy, XI MEXICAN LAW REVIEW (2019). 
a source for inspiration, and I will defend the participation of citizenship as the most effective way to make this transformation a reality. In other words, in this article I aim to think about the difficult task of transforming an authoritarian constitutionalism into a kind of popular constitutionalism.

\section{Mexico Has Lived under Authoritarian Constitutionalism}

Authoritarian constitutionalism refers to the exercise of power within the framework of a liberal democratic constitution. ${ }^{5}$ Of course, a constitution that does not fulfill the promises of constitutionalism ${ }^{6}$ makes authoritarian constitutionalism a thin constitution.

So, authoritarian constitutionalism emphasizes the tension between the exercise of power within ill-defined limits, lack of accountability, and how the ruling elites execute and mask its violence under the forms of the constitution $^{7}$ and the idea of constitutionalism. This tension makes authoritarian constitutionalism a perplexing but not absurd category; perplexing because of the inconsistencies it points out and helps us both understand and critique. These inconsistencies exist between the functions that some constitutional provisions fulfill in a liberal democracy (limiting the power of the state and empowering those who would otherwise be powerless), and the liberal democratic ideology behind constitutionalism, on the one hand, and the functions that those same provisions and a constitutionalist discourse fulfill in authoritarian constitutionalism, on the other.

In a liberal democracy, where power is widely and evenly distributed, the provisions that theoretically have the purpose of limiting power do have this effect. ${ }^{8}$ Conversely, authoritarian constitutionalism turned liberal democratic constitutions inside out. ${ }^{9}$ Elites used constitutions to achieve goals, such as controlling political opponents, or to bolster a regime's claim to legal legitimacy in so far as it served the regime's interests. ${ }^{10}$ Consequently, the application of constitutional provisions varied according to the interests of the ruling elite.

5 Niembro, supra note 4.

6 Ogendo Hastings W. Okoth, Constitutions without Constitutionalism: Reflections on an African Political Paradox, in Constitutionalism and Democracy: Transitions in the Contemporary World 60-66 (Douglas Greenber, S. Katz, B. Oliviero and S. Wheatley eds., 1993).

7 The Federalist No. 10, at 75 (James Madison) (Clinton Rossiter ed., 1961).

8 Stephen Holmes, Constitutions and Constitutionalism, in Oxford Handbook of Comparative Constitutional Law 154 189, 207 (Michel Rosenfeld and András Sajó eds., 2012).

9 Turkuler Isiksel, Between text and context: Tuskey's tradition of authoritarian constitutionalism, 11

INT'L F. CONST. L., 702, 714 (2013).

10 Mark Tushnet, 2013, at 53, 62, 69. 
Under authoritarian constitutionalism constitutions do not effectively limit power or empower those who would otherwise be powerless. However, as we will see, that doesn't impede ruling elites from trying to use the constitution as legitimate force. When that is no longer possible, they use the constitution to stabilize the regime generating continuous aspirations while making implausible any real change.

Thus, under authoritarian constitutionalism the liberal democratic constitution does not limit ruling elites. For example, the rules that regulate elections serve to coordinate succession of power in a peaceful manner without it entailing an empowerment of the electorate; horizontal and vertical separation of powers is a mechanism of coordination amongst elites but not of mutual control; the rules that prescribe sanctions against the improper exercise of public service are used to control subordinates, etc. In this way, the fact that ruling elites use the language of liberal democratic constitution does not report any benefit to the citizens. Actually, it makes things even worse because constitutional discourse is used to cloak authoritarian functions, which can lead to the disenchantment or rejection of constitutionalism, and to authoritarian transitions.

In my opinion, this instrumental use and flexible application of the constitution tells us more about the ideology of the elites. Indeed, according to Linz, based on Theodor Geiger, authoritarian ruling elites have a more emotional than rational mentality-in contrast to an ideology in terms of rigor--which allows them to react in a more flexible way in different situations. Mentality is fluctuating and with little rigor, close to the present or the past, without being utopian. ${ }^{11}$ Unlike ideologies, mentalities are weak and flexible.

Therefore, the ideas that guide authoritarian ruling elites allow them to adopt constitutions with a content that in theory must limit their power, but that they implement according to their convenience. Their pragmatic mentality allows them to easily adapt to upcoming situations and to adopt liberal democratic dispositions to the extent that these yield a benefit. ${ }^{12}$

Likewise, the liberal democratic constitution helps ruling elites to adopt a spoken discourse of constitutionalism. Thus, they appeal to the constitution, the rule of law, respect for human rights or the life of democracy. In that sense, the text matters insofar as it gives the ruling elite the material basis which make it more credible - to use to their benefit the spoken discourse of constitutionalism. ${ }^{13}$ Of course, there is no normative architecture - that is, conventions and practices, principles and understandings ${ }^{14}$ - that makes

11 Juan J. Linz, Totalitarian and Authoritarian Regimes 162, 163 (Lynne Rienner Publishers 2000).

12 Id., at 162-64.

13 Alan Hunt, Explorations in Law and Society Toward a constitutive theory of LAW 4 (Routledge 1993).

14 Graham Walker, The Idea of Nonliberal Constitutionalism, in EтHNicity AND Group Rights 165 (I. Shapiro and W. Kymlicka eds., 1997). 
constitutionalism a reality. In the mentality of the ruling elite, there is no commitment to the limitation of power.

This is a superficial constitutionalist discourse because it does not further the liberal democratic ideology that is needed for constitutionalism to work properly. I mean values such as individualism, plurality, neutrality, participation, and disagreement. As in cases of authoritarian constitutionalism, its pillars are the conservative cultural values of order, community bent, value consensus rather than contention, etc., and, of course, in authoritarian constitutionalism ruling elites do not make any attempt to undermine them by spreading liberal democratic values.

The ruling elites use this constitutionalist discourse - written and spoken - for ideological purposes. The goal of this discourse is to stabilize domination or engender the belief of being a legitimate domination. ${ }^{15}$ Stabilizing domination might be easier than engendering the belief of its legitimacy, and it is possible that the younger the regime the greater possibilities to develop this belief. Conversely, as time goes by and people realize that the constitution is not respected and the discourse of constitutionalism is just a sham, its legitimating force would tend to reduce.

To achieve these goals, ruling elites need to generate continuous aspirations through the constitution and other legal instruments, even though at the same time they make any substantial change impossible. In this way, the constitution is alienated and turned into an enemy weapon. ${ }^{16}$

\section{A. Creating Continuous Aspirations through the Constitution and other Legal Instruments}

To achieve this purpose, they have to create an illusion of possible change. This can be achieved, for example, by granting rights that formulate the interests of the powerless without changing the conditions-social, economic and institutional power relations - to make them effective.

Commonly, this grant of human rights is accompanied by theories that further the idea that the dogmatic and organic parts of the constitutions are independent or interrelated in a peaceful way. Accordingly, it is possible to make some progress just focusing on human rights. However, as has been argued by Roberto Gargarella based on the Latin American experience, this thesis seems doubtful. Constitutions should be seen as made up of components that are related and interdependent and recognize the special influence that the organization of powers has on the functioning of the entire constitution, and in consequence, the necessary attention that has to be paid to it. Not

15 Raymond Geuss, The Idea of a Critical Theory Habermas and the Frankfurt School 15 (Cambridge University Press 1981).

16 Carlos de Cabo Martín, Pensamiento crítico constitucionalismo crítico 83 (Trotta 2014). 
recognizing this difficult relation among the components of the constitution may hide failures of the political branches to comply with the constitution, blind the presidential hindering of social rights implementation, or ignore the inactivity of Congress to implement participatory clauses. ${ }^{17}$

This logic may explain why, for example, in Latin America in the last decades constitutional amendments have focused on granting more human rights, even though no substantial change has taken place in the vertical organization of power. Moreover, in cases where the organic part of the constitution has been amended to establish more democratic procedures or vehicles for popular participation, in the statutes or in practice, they are not respected. ${ }^{18}$

In those cases, although rights reflect interests of the powerless, they rather further elites' interests. ${ }^{19}$ The logic is that the law has to be responsive in some degree to social needs in order to be repressive, that is, to secure control by ruling elites. ${ }^{20}$ Indeed, the powerless make some minor gains and the elites maintain control over the state. ${ }^{21}$

In fact, without any respect or inclusion of the powerless, it would be very difficult for any constitutionalist discourse to be persuasive. ${ }^{22}$ Creating constitutional aspirations depends on identifying real but partial freedoms and equalities. Delusion is plausible and effective because norms selectively articulate real needs, relations, and potentials of the powerless. ${ }^{23}$

This real, but feigned, achievement of constitutionalism creates an illusion of living in a constitutional state. ${ }^{24}$ It is an illusion because there is no overwhelming evidence that the belief is false. On the contrary, the inclusion of human rights, separation of powers, and some respectful practices make people believe that it is possible to achieve a constitutional state. The discourse satisfies the wish of the people to live in a place where power is limited. However, under the existing conditions it is implausible that this could happen $^{25}$. In other words, there is no evidence that under the existing conditions the constitution will limit power and would be respected without relying on the varying considerations of the ruling elites.

17 Gargarella, 2013, at 157-206.

18 Id., at 148-186.

19 Geuss, supra note 16 , at 38.

20 Philippe Nonet \& Philip Selznick, Law \& Society in Transition: Toward Responsive LAW 29 (Transaction Publishers 2001).

21 Hugh Collins, Marxism and law (Clarendon Press 1982).

22 Terry Eagleton, Ideology An Introduction 14, 15, 26 (Verso 2007).

23 Mark Warren, Liberal Constitutionalism as Ideology: Marx and Habermas, 17 POL. THEORr 511 , 525-526 (1989).

24 Edward Palmer Thompson, Whigs and Hunters The origin of the Black Act 263 (Panteon Books 1975). As E.P. Thompson explains, for law to be able to fulfil its ideological function it must appear as foreign to manipulation and seem fair, being fair on some occasions.

25 Geuss, supra note 16, at. 42. 


\section{B. Making Implausible any Real Change}

At the same time that ruling elites generate continuous aspirations they make any real change implausible. For this purpose, they have to conceal and reproduce reality. For example, they must conceal politics behind the scenes using democratic procedures as a façade ${ }^{26}$, present group interest as the interest of the whole, hinder or obstruct the creation of opposition powers manipulating electoral rules, and co-opt them if they come to existence. ${ }^{27}$

Likewise, ruling elites must conceal the conditions under which normative potentials might be realized. ${ }^{28}$ The dissimulation masks the conditions of realization of a desirable political situation. They highlight some kinds of social contingencies or power relations and suppress others. ${ }^{29}$ For example, they may highlight the importance of human rights provisions while disregarding the organic provisions of the constitution or the uneven power relations in society. Or they may point to frequent elections without considering any other auxiliary precautions. ${ }^{30}$

Elites use the constitution to provide symbols and generate appearances in order to mask contrary practices. ${ }^{31}$ Moreover, elites may make sham constitutional attempts to counteract the conditions that allow them to implement the constitution according to their varying wishes. These conditions are wide corruption, weak civil society, ${ }^{32}$ and rigid verticality in the political system, popular ignorance of the constitution, ${ }^{33}$ material inequality, ${ }^{34}$ and so on.

Among these conditions, one of great importance is the creation of an authoritarian coalition. ${ }^{35}$ This coalition is made up of the provision of ben-

26 Andreas Schedler, The Logic of Electoral Authoritarianism, in Electoral Authoritarianism The Dynamic of Unfree Competition 1, 16 (2006).

27 Geuss, supra note 16, at 13-14.

28 Warren, supra note 24, at 512.

29 Geuss, supra note 16, at 14.

30 Even though frequent and fixed elections were very important for the framers of the American Constitution, they also knew that "A dependence on the people is, no doubt, the primary control on the government, but experience has taught mankind the necessity of auxiliary precautions. This policy of supplying, by opposite and rival interests, the defect of better motives [...]" The Federalist No. 51, at 319 (James Madison) (Clinton Rossiter ed., 1961).

31 Malcolm M. Feeley, Book Review: Law, Legitimacy, and Symbols: an Expanded View of Law and Society in Transition, Michigav LaW Review (1979), at 899. Feeley, 1979, at 905.

32 It is worth recalling that according to Madison restraints need constitutional laws and the vigilant spirit of the people. The Federalist No. 57, at 350 (James Madison) (Clinton Rossiter ed., 1967).

33 Tushnet, supra note 11, at 49. Mark Tushnet says that if participants of a system cannot clearly identify who violates the constitution, then people cannot coordinate themselves against who does it.

34 Gargarella, supra note 18, at 206.

35 Tushnet, supra note 11, at 51. 
efits to other officials, the opposition, political parties, and social powers such as mass media. Therefore, the lack of virtue among men of self-government makes it possible to create an authoritarian coalition between several members of government and private fortunes. This authoritarian coalition renders the constitutional means ineffective. ${ }^{36}$ To use the words of the Federalist Papers, there are no longer any personal motives to resist encroachments or violations of rights and liberties, there is no ambition to counteract ambition, no opposite or rival interest or mutual checks. ${ }^{37}$

Finally, ruling elites may want to misidentify and justify existing power relations. By the misidentification of the causal origins of social phenomena they are removed from the realm of possible political action. Examples include pointing to the constitution as the legal impediment of change, make a subsequent constitutional amendment and subverting the purpose in the laws or in practice. On the other hand, justification makes the prevailing distributions of power something right, proper, and good, such as appealing to the existence of more or less regular elections and formal representative procedures to justify decisions adopted behind the scenes and without public deliberation. ${ }^{38}$

In sum, amongst the ideological functions there is the generation of incessant aspirations in order to keep people in the game, whilst making any real change implausible.

\section{Some Examples}

In other works, I have analyzed in greater depth the practice of authoritarian constitutionalism in Mexico and how constitutional reforms were some of its main tools. For this reason, I will restrict myself to provide only a couple of examples about authoritarian constitutionalism.

In 2013, after several failed attempts, there was an amendment to the Mexican Constitution regarding the oil and hydrocarbon investment regulation that allowed private investment. This amendment was negotiated by a small group of congressmen, government leaders, and party leaders outside congress in what has been called the Board of the Mexican Agreement (Pacto por México).

The Pacto por México was a political agenda set up by the three major political parties when Enrique Peña Nieto came to office. Moreover, they put in place a Board that negotiated and wrote up the law proposals. Of course, there

36 Remember that for republican governments to function properly private fortunes should not be sources of danger, improbability of mercenary and perfidious combination of the several members of government, accountability, and sufficient virtue among men of self government. The Federalist No. 10, at 343 (James Madison) (Clinton Rossiter ed. 1961).

37 The Federalist, supra note 31 , at 319.

38 Warren, supra note 24, at 513-514. 
was no transparency in their discussions; they just turned in the proposal to Congress to be approved.

In fact, according to article 135 of the constitution, this amendment required the approval of a super majority in both houses and a majority of state legislatures. Even though this procedure is theoretically rigid, the constitutional amendment was approved by the House of Representatives the next day after receiving it from the Senate, and the state legislatures passed it in just a few days. Moreover, according to the members of the leftist opposition, there were some irregularities in the committees of the House. And some state legislatures approved the amendment within hours after receiving it without any further proceedings. ${ }^{39}$

After state legislatures passed the amendment, Congress made a public declaration of its constitutionality. Some days later the President, congressman of PRI and the members of the right wing party defended this constitutional amendment in a big TV presentation arguing that it would promote the country's development, and make electricity and combustibles cheaper. Moreover, ruling elites argued that the amendment was inevitable under current conditions and emphasized that the amendment respected all the rules established on the constitution, so it was constitutional.

In this case, a critical theory might point out at least three critical ideological flaws. First, it could call our attention to how ruling elites argued that a particular interest of some faction, the oil companies, is presented as the general interest of the population. Second, it could question how inevitable the amendment was. And finally, it would denounce how a representative and federal procedure works neither to refine nor to enlarge public views nor to discern public interest. ${ }^{40}$ In other words, how a democratic procedure was used as a façade of democracy.

Another noteworthy example is the constitutional creation of the national anticorruption system through a reform published in the Official Journal of the Federation on May 27 2015, a few months after a special news report by Aristegui Noticias was broadcasted on November 2014 about President Enrique Peña Nieto's white house, built by Grupo Higa, one of the main contractors in his administration. ${ }^{41}$ Even though the anticorruption reform was pushed forward by the academy and civil society, it is conspicuous that it was published a few months after the scandal that the aforementioned news report caused and that undermined the legitimacy of the government in turn. In fact, the Decree by which the anticorruption reform was published prescribed in its transitory articles the entry into force of some of its minor provisions on the day following its publication and the deferred entry into force of the more

39 Tania Montalvo, 2013 deja 12 reformas, pero 11 están a medias, Animal Político, Dec. 16, 2013, https://wrwreanimalpolitico.com/2013/12/2013-deja-12-reformas-que-se-aplicaran-hasta-2014/.

40 Madison, [1787] 1961, at 76-79.

41 Aristegui Noticias, 2014. 
important dispositions, until the regulatory laws were issued on the following 180 days.

In this manner, the constitutional reform regarding the fight against corruption served as an immediate response to the legitimacy crisis that the government went through at the time as a consequence of the news report that was published. At the same time, the transitory articles allowed the government to defer its implementation, which is currently pending. What is more, to this very date the Anticorruption Prosecutor is yet to be appointed. From this episode we must not forget the suspicious firing of the journalist Carmen Aristegui in March 2015 after she made the news report public.

\section{Popular Constitutionalism as a Source of Inspiration For Constitutional Transformation}

The constitutional transformation that we have voted for needs ideas that serve as a source of inspiration. For the constitutional transformation to take a democratic, participatory and egalitarian direction, we can draw from the popular constitutionalism trend. ${ }^{42}$ In general terms, popular constitutionalism is particular because it broadly distributes (among the population) the responsibility over the constitution and it reinforces the people's role in its interpretation. ${ }^{43}$ In Kramer's words: "The people's role is not limited to occasional acts of constitutional creation, but to an active and continuous control about the interpretation and implementation of the Constitution." 44 According to the Stanford professor, it is not enough that the people can create constitutional law through the constitutional reform process; it must also vindicate its role as a constitutional interpreter. ${ }^{45}$

Popular constitutionalism recognizes that the public debate over the constitution is carried out independently from legal interpretations or even against itself. ${ }^{46}$ The constitution obliges all governmental powers, and none of them-the judiciary power included-has any special authority over it. If judges can interpret the constitution it is not because they have any specific attributes that make them more able for the task or because they have to do it exclusively, but because the constitution compels them as much as any other.

42 See Roberto Niembro \& Ana Micaela Alterio, Constitutional Culture and Democracy in Mexico. A critical view of the hundred-year-old Mexican Constitution, in Constitutional Democracy IN CRISIS? (Mark Graber, Sanford Levinson \& Mark Tushnet eds., 2018).

43 Mark Tushnet, Taking the Constitution Away from the Courts 108 (Princeton University Press ed., 1999).

44 Kramer, 2004, at 959, 973, 980.

45 Kramer, 2005, at 1344.

46 Tushnet, 2006, at 991. 
According to this outlook, the judiciary power is another agent of the people whose duty is to be an opinion leader, without imposing a unique vision. ${ }^{47}$

Populars don't intend to say that the people's interpretation is the only interpretation or even the best one ${ }^{48}$ but to remind us that people as much as judges can make mistakes, thus the inclination for one or the other depends on the outlook that is held on the function of judges and on the people's ability to interpret the constitution. On one hand, people can be considered to be purely emotional, ignorant and limited, in contrast to informed, attentive and intelligent elites, in which case judges will be the only constitutional interpreters ${ }^{49}$ in a way that the discussion ends when they state what Law is. On the contrary, the right of the judges to interpret the constitution can be recognized, without implying that the possibility to do it outside courthouses is also affected. ${ }^{50}$

Hence, on one side there are those committed to the government of the people who are pessimistic and afraid about what it could produce and therefore seek to establish extra guarantees, and on the other hand there are those that have greater faith in the citizen's ability to self-govern responsibly, without the risks that it entails being enough to control them by non-democratic means. The choice between one mean and the other-Kramer follows-is a decision of the people.

Another distinctive trait of this trend is the way to understand the relationship between politics and law, because the former is not mere will and decree, and the latter is not pure rationality. Both need each other reciprocally and are different phases of a longer and inclusive social process. The constitution is their confluence point and therefore it stands as a legal-political rule and not only as a legal one. Treating it according to this latter approach has mistakenly made judges and lawyers believe that its interpretation belongs to them exclusively ${ }^{51}$. Nevertheless, for Populars the constitution goes beyond legal bound$\operatorname{aries}^{52}$. Hence, they seek to end the distinction between a constitution in which principles reign and over which the tribunal rules and a political and nonprinciple oriented where mere majoritarian preferences rule. On the contrary, they seek a policy oriented by the Declaration of Independence's principles ${ }^{53}$ and a constitutional law that takes into account the legal and the political. ${ }^{54}$

However, the school of popular constitutionalism is not homogeneous. In fact, there are important differences among its followers, because for some of

\footnotetext{
47 Kramer, 2001, at 49, 53, 82.

48 Tushnet, supra note 43, at XI.

49 Kramer, supra note 44, at 242.

50 Tushnet, supra note 43, at 6-7.

51 Post, 2010, at 1319-1350.

52 Post \& Siegel, 2007, at 29.

53 Tushnet, supra note 43, at 187.

54 Tushnet, supra note 46, at 992.
} 
them judges can be an instrument to channel popular expression. This last strand, represented by Post and Siegel and known as democratic constitutionalism, considers that the legitimacy of the constitution lies in its ability to be recognized by citizens as their constitution. This way to conceive constitutionalism is upheld by traditions of popular activism that authorize citizens to bring forward claims about the meaning of the constitution and to oppose the government when they consider that it doesn't respect them. In this process, courts play a legal-political role that is constitutionally attributed to them. ${ }^{55}$

In fact, according to Post and Siegel the Supreme Tribunal is a possible collaborator of democratic institutions in the construction of constitutional meaning, like a catalyst of popular constitutionalism. The relationship between constitutional judges and democracy does not amount to zero, because the former can fortify the latter. ${ }^{56}$ Just as the people's constitutional compromises are inspired and upheld by the constitutional law created by courts, this right is inspired and upheld by those commitments. ${ }^{57}$

In any case, I am now interested in highlighting that citizens are authors of the mentioned right and that they should regard themselves as such. Democratic beliefs about the constitution authorize and empower citizens to debate about its sense, even when they differ from the legal interpretation. They aim at creating a series of attitudes and practices that trigger and sustain the involvement of people in constitutional matters. Thus, their theoretical proposal seeks to account for the different spaces, practices and means, through which the constitutional debate takes place, and which, according to them, are ignored or undervalued by traditional theory. ${ }^{58}$

In this way, for Post and Siegel, popular deliberation of constitutional matters, whether it ends up being reflected in institutional reforms or not, is a guideline for legal action. This does not mean that judges are limited to reflect social developments, but that they participate in a social debate about the meaning of the Constitution, which is a necessary condition for democracy. ${ }^{59}$ From that point of view, the Tribunal is in a permanent dialogue with political culture, from which it cannot stray too far if it wishes to prevent a crisis. ${ }^{60}$ In this respect collective deliberation is the last source of legitimacy of constitutional law, which requires institutions that allow the people to be involved in the creation of Law. Therefore, popular participation is the democratic basis of the constitution, and it must not be regarded with suspicion, on the contrary, it must be considered as a means to mediate the conflict. ${ }^{61}$

\footnotetext{
55 Post \& Siegel, supra note 52, at 373-433.

56 Id., at 404.

57 Post \& Siegel, 2004, at 1038.

58 Siegel, 2001-2002, at 320-326.

$59 I d$, at 315 .

60 Post \& Siegel, 2003, at 26.

61 Siegel, 2006, at 1339-1350.
} 
Hence, they consider that social movements shape the constitutional sense by generating new understandings that guide the official postures. Therefore, they propose to surpass traditional descriptions of how constitutional changes are made, for more complex one that takes account of the importance of said movements. In this way, they detract from court-centric descriptions of North American constitutional tradition, because, in their opinion, they leave aside the existing communication channels between legal reasoning and claims raised outside courthouses. ${ }^{62}$

Social movements are configured in part of what they call constitutional culture, which is an argumentative practice carried out both within and outside governmental institutions, beyond formal channels of creation of Law recognized by the legal system. Citizens as well as rulers can set different constitutional postures, which are in a dynamic balance and which are conditioned reciprocally. No authority, not even the High Tribunal, would have the authority to set the sense of the constitution without the possibility of it being challenged. ${ }^{63}$

In this manner, the constitution and with it the common community to which the debaters belong to, are expressed through argumentation, which is linked to social structures that mediate between the one that sends and the one that receives the message. That said, for these new constitutional conceptions to last, they need to persuade. Hence the recommendation to use constitutional language to issue their petitions and appeal to the traditions of the people they address. ${ }^{64}$ Thus, they speak of two restrictions that distinguish these social movements as creative agents of constitutional law. The first one is the "condition of consent", that is, not to use coercion but persuasion. They must respect the authority even if in some occasions they perform irregular and disruptive, or even illegal procedural activities. Secondly, there is the "condition of public value", because to convince citizens that don't belong to their ranks, they must express their values as public values, just like the women's suffragist movement did.

In this way, they conceive social movements as mediators between the government and the citizenry, allowing citizens to express their concerns, criticisms or their total resistance to the governmental policy. Among the functions of social movements there is the one to educate and incite public opinion to modify the agenda of electoral policies, as well as to model the development of constitutional law. Even so they recognize that their informality, partiality and lack of public responsibility make them a bad candidate to speak for the people, apart from the fact that they only represent some people. Therefore, they can only speak for everyone if they succeed and their interpretation is accepted by the authorities that declare the content of constitutional law. ${ }^{65}$

\footnotetext{
62 Siegel, supra note 58, at 300.

63 Id., at 303-344.

64 Siegel, supra note 61, at 1350-1366.

65 Siegel, 2005, at 260-270.
} 
In sum, popular constitutionalism is based on the idea that all of us must participate in the configuration of constitutional law through our political actions, ${ }^{66}$ as this gives citizens a central role in the interpretation of the constitution and demystifies the dominant visions on the impact of court's decisions; it shows the way in which society influences, rebuilds and sometimes undermines the value of legal decisions, it pushes forward a greater participation in political and economic structures, ${ }^{67}$ and defends a compartmentalized look of the constitution's control, according to which no branch of State power has the right to claim supremacy over the others. ${ }^{68}$

\section{Popular Participation as an Indispensable Mechanism for Constitutional Transformation}

It is too soon to know if the authoritarian coalition of the past has been completely relegated from public power. Now, irrespective of whether that happens or not, it is essential to defend popular participation as a necessary mechanism for constitutional transformation. In my opinion, the constitutional transformation in Mexico needs citizens that know, understand and interpret the constitution in a non-legalistic way that is to say, creating a constitutional culture ${ }^{69}$. It's true that to know the constitution a certain degree of stability in its text is required-which the Mexican Constitution lacks. However, advocating for stability cannot become an argument in favor of constitutional fundamentalism, that is, to consider that the constitution is a sacred instrument that cannot be reformed. One of the traits of a democratic constitution is the possibility of reforming it in accordance with the changes in interests or popular preferences that are configured through social deliberation. ${ }^{70}$

In this frame of mind, one of the institutions that is fundamental to achieve the knowledge and understanding of the constitution is popular participation in the constitutional amendment procedure prescribed in article 135 of the Mexican Constitution, ${ }^{71}$ which must incorporate a sort of mechanism-initia-

66 Tushnet, supra note 43, at 157.

67 Roberto Gargarella, Una disputa imaginaria sobre el controljudicial de las leyes. El constitucionalismo popular frente a la teoría de Nino, in El CANON NEOCOnstitucional 403, 407-420 (M. C. Jaramillo ed., 2010).

68 Gargarella, 2007.

69 Niembro \& Alterio, supra note 42, at 353.

70 Velasco, 2002, at 38.

71 Article 135 of the constitution currently in force establishes:

Art. 135.- The present constitution can be added to or be reformed. For the additions or reforms to become a part of it, it is required that the Federal Congress, by vote of two thirds of the individuals present, agrees upon the reforms or additions, and that these are approved by the majority of the legislatures of the States and Mexico City. 
tive, referendum, etc. - of deliberative participation ${ }^{72}$ that involves citizens in a learning and understanding process of the constitution and that allows the interaction between informal public opinion and the institutions on a constitutional level. ${ }^{73}$ One of these fundamental mechanisms to shape a constitutional culture is deliberative participation in constitutional amendment procedures, ${ }^{74}$ such as open meetings, participatory forums, public hearings, popular initiatives, referenda ${ }^{75}$ or deliberative polling. ${ }^{76}$ Participatory constitutional amendments would allow the citizenry to learn and understand the contents of the constitution, and it is a way of interaction between public opinion and institutions. ${ }^{77}$ Participatory constitutional amendments have similar qualities to the ones Tocqueville found in juries as a republican institution that "places the real direction of society in the hands of the governed or of a portion of them, and not in the hands of those governing."78 For Tocqueville, a jury has the following qualities: it serves to give the mind of all citizens a part of the mind habits of the judge. It spreads in all classes respect for the thing judged and for the idea of right, it teaches men the practice of equity and not to retreat from a responsibility for their own actions, and makes citizens feel they have duties to fulfill toward society and that they belong in their government. It serves to form the judgment and to augment the natural enlightenment of the people. It is a free school, where each juror comes to be instructed about his rights and enters into daily communication. ${ }^{79}$ And it's likely that when citizens make decisions in a jury they are attentive to proceedings and focused on deciding the cases correctly. ${ }^{80}$ Likewise, participation in constitutional amendment processes makes citizens likely to be attentive to the procedure and focused on verifying that the amendment is correct.

Education through participation requires deliberation. ${ }^{81}$ Deliberation can be achieved by different institutional mechanisms, such as two votes separated by a period of time for deliberation, or the requirement of electing a

The Federal Congress or the Permanent Commission in its case will compute the votes of the Legislatures and the declaration of the approval of the additions or reforms.

72 Alterio, 2017, at 209-231.

73 Habermas, 2000, at 374-375; Pateman, 2003, at 46.

74 Siegel, "Constitutional Culture, Social Movement Conflict," 1339.

75 Gabriel Negretto, "Constitution-Making in Comparative Perspective," Oxford Research Encyclopedia of Politics (July 2017): at 17-19.

76 James Fishkin and Gombojav Zandanshatar, "Deliberative Polling for Constitutional Change in Mongolia: An Unprecedented Experiment", Constitution Net, September 20, 2017, http://www.constitutionnet.org/news/deliberative-polling-constitutional-change-mongolia-unprecedentedexperiment.

77 See Habermas, supra note 73, at 374, 375; Pateman, supra note 73, at 46.

78 See Tocqueville, Democracy in America, at 445.

79 Id., at 273-277.

80 Lahav, 2014, at 1036-1038.

81 Farrel, Harris \& Suiter, 2017, at 131. 
new decision maker to approve the amendment. ${ }^{82}$ The idea is to incorporate popular participation provided with information and time to deliberate. ${ }^{83}$

In comparative constitutional law there are very useful examples of how to design a participative and deliberative mechanism. For example, referendum design needs to avoid manipulation from the elites and an accurate drafting of the question. It is necessary to avoid high percentage for approval in order to encourage mobilization, and there should be enough time to deliberate. ${ }^{84}$

Now, beyond the modification of the constitutional amendment procedure, it is necessary to encourage popular interpretation of the constitution in the informal public sphere, in order to create a citizen constitutional culture. From this perspective, popular interpretation of the constitution is an open and incomplete process that requires active participation of the citizens. Conflict and disagreement about its content and function are foreseeable, ${ }^{85}$ but conflict and disagreement generate deliberation, social mobilization, and the creation of civil associations.

Through deliberation, it is possible to learn and understand a constitution that contains ambiguous and vague terms, as well as the structures and processes it establishes. In fact, constitutional clauses do not have only one meaning and they relate in complex ways. In other words, learning and understanding the constitution is done by a reflective process of deliberation. ${ }^{86}$ Through deliberation we acquire or modify our knowledge about constitutional dispositions, their origin, the possible interpretations of the text, how they are related, what purposes they can achieve, etc. Regarding the constitution, before the deliberative process, not even the best expert can know and understand the constitution or consider that his interpretation is the correct one, for through the collective process of deliberation the interpreter collects, classifies and elaborates the necessary information to interpret it, for example, the characteristics that arise in concrete cases or the facts that stem from the cultural evolution of society. ${ }^{87}$

This does not mean constitutional interpretation is limited to the constitutional text. The language of the constitution is a point of departure that in some degree constrains constitutional debates, but it is not an unchangeable text and its interpretation is disputable. Hence, popular interpretation of the constitution goes beyond the constitutional text. Otherwise, political struggles are formalized and reduced to the terms established by legal experts. ${ }^{88}$ If this

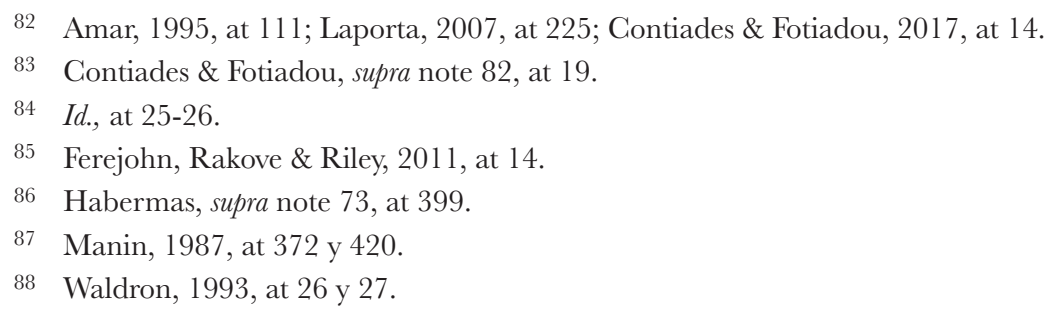


should be the case, power remains on the ones that participate in constitutional amendments procedures and in the judicial branch, as the only authority to establish and interpret the constitution. ${ }^{89}$

Moreover, through deliberation the people help establish what the constitution means, accomplishing a rational, and not only emotional, respect for the constitution. In democracy, the constitution motivates us because it is ours, it is interpreted through a rational debate, ${ }^{90}$ which is rational because we give it meaning through the exchange of reasons about its content and interpretation. ${ }^{91}$

The function of social movements in the process of constitutional interpretation is to spontaneously present new interpretations of the constitution, either because they defend a different perspective of a stale problem, they problematize and make visible issues that were considered to be peaceful before, they provide contributions, commentaries and interpretations, or because they articulate interests and needs. ${ }^{92}$ The existence or not of social mobilization over the interpretation of the constitution is largely conditioned by the role that citizens and law professionals consider that the people have over constitutional interpretation vis-à-vis the judges. ${ }^{93}$ If the people consider that through social mobilization changes to the interpretation of the constitution can be achieved, and the institution remains porous to subjects, appraising orientations, contributions and programs, acceptance and adherence can be generated to it. $^{94}$

The relationship between social mobilization and civil organizations is pretty obvious, because these are the basis for social mobilization and the ones that form opinion. ${ }^{95}$ Besides, it is through civil associations that we learn about democracy ${ }^{96}$, because we experience firsthand the restraint of power. The importance of civil associations for the conformation of a constitutional culture in the period after the establishment of the American Constitution has been highlighted by Mazzone, who argues that civil associations gave the people the experience to administer and self-govern. ${ }^{97}$

Furthermore, it is necessary to stress the importance of the complementarity between participatory constitutional amendments and participation in the public sphere at shaping public opinion. Shaping a constitutional culture requires both. On the one hand, even in countries like Mexico with a high

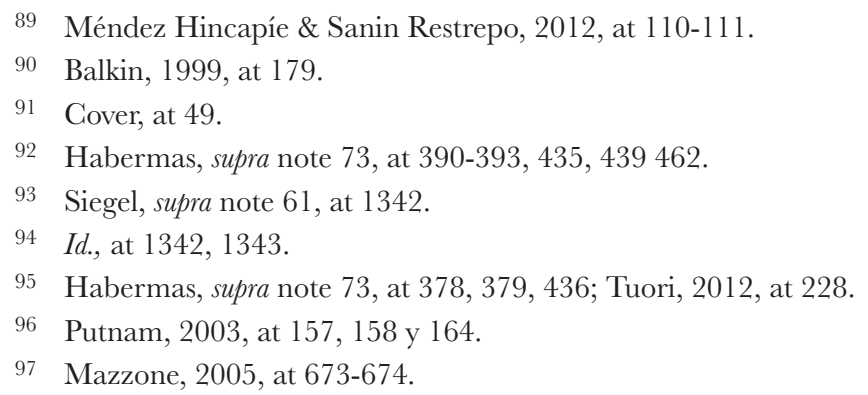


Esta revista forma parte del acervo de la Biblioteca Jurídica Virtual del Instituto de Investigaciones Jurídicas de la UNAM

rate of constitutional amendments, habits of discussing and interpreting the constitution are acquired by daily participation. Only constant communication and participation can foster a constitutional culture. On the other hand, participation in the public sphere is not enough, if there are no institutional mechanisms that oblige public officials to dialogue with the people. ${ }^{98}$

\section{Gonclusions}

Mexicans have reached the year 2018 with the will to change the situation of our country, because we want to leave behind the severe and complex humanitarian crisis we live in. In order to achieve that, we have democratically chosen a government that has promised to accomplish this. Nevertheless, our duty must not end there. After the election we must continue participating, discussing, demanding and criticizing, because the construction of an authentically democratic country is a job for each one of us that is affected by its decisions. Only through participation and continuous deliberation we will achieve a constitutional transformation.

Mexican scholars and constitutional lawyers have a special responsibility in this transformation, for we propose and discuss different conceptions of constitutional law. For a long time, Mexico has followed elitist constitutional theories that are focused on expert opinions and a minimalist democratic conception that forsakes we the people. It is time to look at different perspectives. Popular constitutionalism could be a useful theory that inspires us in our constitutional transformation because it is centered on popular participation and democratic equality. We cannot forget that without the involvement of the citizenry there is no chance of a constitutional transformation.

98 Post, 2016, at 34-36.

Received: February 18th, 2019.

Accepted: June 06 ${ }^{\text {th }}, 2019$. 